\title{
3-D Numerical Study of Mechanical Behaviors of Pile-anchor System
}

\author{
Richeng Liü ${ }^{1,2, a}$, Bangshu Xu2 2,b , Bo Li ${ }^{1, c}$, Yujing Jiang ${ }^{1, d}$ \\ ${ }^{1}$ Graduate School of Engineering, Nagasaki University, Nagasaki 8528521, Japan \\ ${ }^{2}$ School of Civil and Hydraulic Engineering, Shandong University, Jinan 250061, China \\ a email:my1122002006@126.com, bemail:xubangshu@sdu.edu.cn \\ c email:libo@nagasaki-u.ac.jp, d email: jiang@nagasaki-u.ac.jp
}

Key words: pile-anchor system; sensitivity analysis; numerical simulation; FLAC ${ }^{3 D}$

\begin{abstract}
Mechanical behaviors of pile-soil effect and anchor-soil effect are significantly important in supporting engineering activities of foundation pit. In this paper, finite difference method (FDM) was utilized to perform the numerical simulation of pile-anchor system, composed of supporting piles and pre-stressed anchor cables. Numerical simulations were on the basis of the foundation pit of Jinan's West Railway Station, and 3D simulation analysis of foundation pit has been prepared during the whole processes of excavation, supporting and construction. The paper also analyzed the changes of bending moments of piles and axial forces of cables, and discussed mechanical behaviors of pile-anchor system, through comparisons with field monitoring. The results show that the parameters concluding vertical gridding's number, cohesion of pile and soil, and pile stiffness have robust influences on supporting elements' behaviors. Mechanical behaviors of supporting pile and axial forces of anchor cable changed dramatically, indicating that the potential failure form was converted from toppling failure to sliding failure.
\end{abstract}

\section{Introduction}

Pile-anchor supporting system is consisted of supporting pile and anchor cable. The system can robustly control the displacement of soil, by utilizing the passive stress mechanism of pile and active stress mechanism of anchor cable, and finally maintain the safety of the foundation pit. This system can strictly dominate the displacement of foundation pit, having the merits of strong supporting effects, low-cost and easy-construction [1].

Shen and Bang [2] studied the influents of supporting parameters during the process of excavation, using the finite element method (FEM). Jiang and Lin [3] exhibited an expression to calculate the maximum displacement of pile-anchor supporting system, based on the abundant monitoring data. Their expresses theoretically depicted the relations of maximum displacement and various engineering aspects. However, the thorough understanding of mechanical behaviors of pile-anchor supporting system is still a difficult task, due to the complexities and uncertain of geo-technical conditions.

In this paper, finite difference method (FDM) was utilized to perform the numerical simulation of pile-anchor system, composed of supporting piles and pre-stressed anchor cables. Numerical simulations were on the basis of the foundation pit of Jinan's West Railway Station, and 3D simulation analysis of foundation pit has been performed during the whole processes of excavation, supporting and construction. 


\section{Project overview}

The foundation pit of station square located in Jinan city of Shandong province, China, with a length of $470 \mathrm{~m}$ and a width of $346 \mathrm{~m}$. The depth of the foundation pit is approximately $15 \mathrm{~m}$, and the underground water level is in the range of $-14 \mathrm{~m} \sim-19 \mathrm{~m}$. The foundation is mainly composed of clay soil, as well as a portion of land pebble.

According to the engineering geology, hydrogeology, the surrounding environment and the correlated technical specifications, the foundation pit of station square is designed with pile-anchor supporting system. The depth of the foundation pit is $14 \mathrm{~m}$. The pile-anchor supporting system is composed by a row of pile and four rows of pre-stressed anchor cables, as shown in Fig. 1.

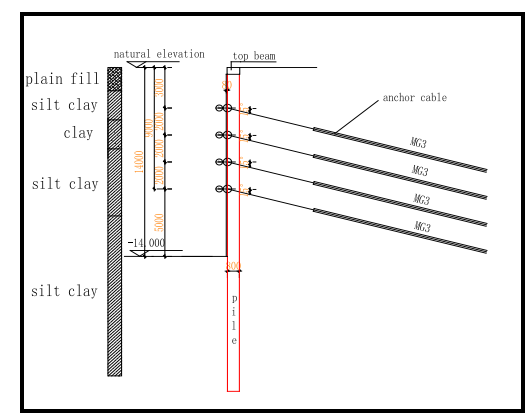

Fig.1 Supporting scheme

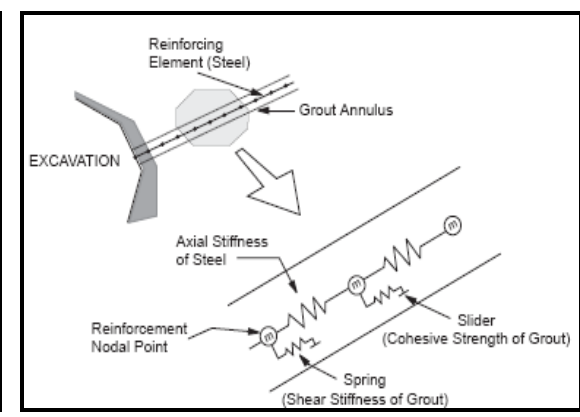

Fig.2 Mechanical representation of fully bonded reinforcement

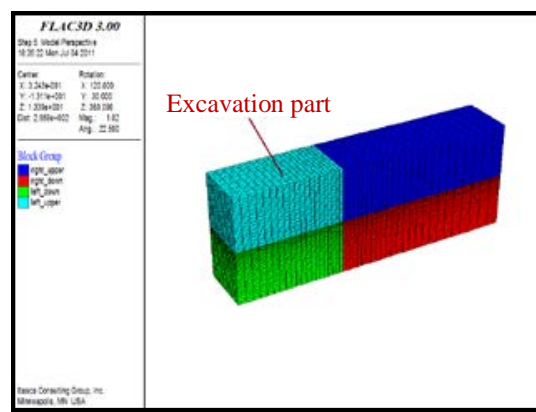

Fig.3 calculating model

\section{Basic theories}

The interaction effects of cable, grout and rock/soil are investigated by using spring-slider model system. This model can reflect the shear properties of interaction between cable and rock. The maximum shear force robustly depends on the shear stiffness of grout. The shear stiffness $K_{g}$ of grout for unit thickness can be expressed by:

$$
k_{g}=\frac{2 \pi G}{\ln (1+2 t / D)}
$$

where, $G$ is the shear modulus of grout, $t$ is the thickness of grout annular and $D$ is the diameter of anchor cable. The shear force $\tau_{g}$ of grout intersection can be calculated by:

$$
\tau_{g}=\frac{G}{(D / 2+t)} \frac{\Delta u}{\ln (1+2 t / D)}
$$

where, $\Delta u$ is the relative displacement of grout and rock/soil.

In evaluating the axial forces that develop in the reinforcement displacements are computed at nodal points along the reinforcement axis, as show in Fig. 2. Out-of-balance forces at each node are computed from axial force in the reinforcement, as well as shear forces contributed through shear intersection along the grout annulus. Axial displacements are computed by integrating the nodal accelerations using the out-of-balance axial force and a mass lumped at each node. 


\section{Modelling and parameters}

The height of the model is about 2.1 times of the depth of excavation, while the length of the model is about 3.3 times of the length of excavation. The length of the model is $130 \mathrm{~m}$, with the depth of $30 \mathrm{~m}$. The length of excavation is $39 \mathrm{~m}$, with the depth of $14 \mathrm{~m}$, as shown in Fig. 3. Physical and mechanical properties of soils, cables and piles are shown in Tables $1 \sim 3$.

Table1 Physical and mechanical properties of soils

\begin{tabular}{|c|c|c|c|c|c|c|c|}
\hline Number & Soil type & $\begin{array}{l}\text { Thickness } \\
\text { of soil (m) }\end{array}$ & $\begin{array}{l}\text { Modulus of } \\
\text { deformation } \\
\text { (MPa) }\end{array}$ & $\begin{array}{c}\text { Poisson's } \\
\text { ratio }\end{array}$ & $\begin{array}{c}\text { Saturated unit } \\
\text { weight } \\
\left(\mathrm{kN} / \mathrm{m}^{3}\right)\end{array}$ & $\begin{array}{c}\text { Cohesion } \\
\text { (KPa) }\end{array}$ & $\begin{array}{c}\text { Internal } \\
\text { friction angle } \\
\left(^{\circ}\right)\end{array}$ \\
\hline 1 & plain fill & 1.5 & 13.17 & 0.27 & 19.0 & 10.0 & 10.0 \\
\hline 2 & silt clay & 2 & 20.70 & 0.30 & 19.3 & 26.3 & 19.4 \\
\hline 3 & silt & 2 & 27.33 & 0.28 & 19.1 & 25.7 & 23.4 \\
\hline 4 & silt clay & 5 & 17.31 & 0.32 & 19.6 & 25.0 & 21.9 \\
\hline 5 & silt clay & 11 & 20.49 & 0.30 & 19.4 & 24.8 & 21.0 \\
\hline 6 & clay & 10 & 26.40 & 0.30 & 19.6 & 34.2 & 24.9 \\
\hline 7 & silt clay & 25 & 30.33 & 0.30 & 19.4 & 45.7 & 22.9 \\
\hline
\end{tabular}

Table2 Physical and Mechanical Properties of Anchor Cable

\begin{tabular}{|c|c|c|c|c|c|c|c|c|}
\hline $\begin{array}{l}\text { Num-b } \\
\text { er }\end{array}$ & Tyре & $\begin{array}{l}\text { Density } \\
\rho \\
\left(\mathrm{kg} / \mathrm{m}^{3}\right)\end{array}$ & $\begin{array}{c}\text { Elasticity } \\
\text { modulus } \\
\mathrm{E}(\mathrm{GPa})\end{array}$ & $\begin{array}{l}\text { Cross-section } \\
\text { area } \\
\mathrm{A}\left(\mathrm{mm}^{2}\right)\end{array}$ & $\begin{array}{c}\text { Grout } \\
\text { cohesion } \\
\mathrm{C}_{\mathrm{g}}(\mathrm{N} / \mathrm{m})\end{array}$ & $\begin{array}{c}\text { Grout } \\
\text { stiffness } \\
k_{g}(\mathrm{~N} / \mathrm{m} / \mathrm{m})\end{array}$ & $\begin{array}{c}\text { Grout } \\
\text { perimeter } \\
P_{g}(\mathrm{~mm})\end{array}$ & $\begin{array}{l}\text { Tensile } \\
\text { strength } \\
F_{t}(\mathrm{KN})\end{array}$ \\
\hline 1 & $\begin{array}{l}\text { Freedom } \\
\text { segment }\end{array}$ & 7800 & 195 & 181.37 & 1 & 1 & 471 & 337.35 \\
\hline 2 & $\begin{array}{c}\text { Anchorage } \\
\text { segment }\end{array}$ & 7800 & 195 & 181.37 & $2 \times 10^{5}$ & $1.75 \times 10^{7}$ & 471 & 337.35 \\
\hline
\end{tabular}

Table3 Physical and Mechanical Properties of Pile

\begin{tabular}{|c|c|c|c|c|c|c|c|c|c|}
\hline Number & Type & $\begin{array}{l}\text { Density } \\
\rho \\
(\mathrm{kg} / \mathrm{m} 3)\end{array}$ & $\begin{array}{l}\text { Elasticity } \\
\text { modulus } \\
\mathrm{E}(\mathrm{GPa})\end{array}$ & $\begin{array}{c}\text { Poison's } \\
\text { ratio } \\
v\end{array}$ & $\begin{array}{c}\text { Cross-section } \\
\text { area } \\
\mathrm{A}\left(\mathrm{mm}^{2}\right)\end{array}$ & $\begin{array}{l}\text { Cohesion } \\
\text { of pile } \\
\text { and soil } \\
\text { Pg(N/m) }\end{array}$ & $\begin{array}{l}\text { Interface } \\
\text { stiffness } \\
k_{g}(\mathrm{~N} / \mathrm{m} / \mathrm{m})\end{array}$ & $\begin{array}{c}\text { Friction } \\
\text { angle } \\
\phi_{g}\end{array}$ & $\begin{array}{c}\text { Pile } \\
\text { perimeter } \\
P_{g}(\mathrm{~mm})\end{array}$ \\
\hline 1 & pile & 2500 & 31.5 & 0.3 & 5024 & $0.96 \mathrm{e} 7$ & $1.3 e 7$ & 9.6 & 252 \\
\hline
\end{tabular}




\section{Results and analysis}

Figs. 4(a) and 4(b) show the results of bending moment of pile and axial force of anchor cable with varying grid layers in the vertical direction in numerical model. With the increment of grid layer, the bending moment of pile and the axial force of anchor cable increase too. When the number of grid layer exceeds 50, the increment of bending moment and axial force is not remarkable, however, the computing time is increasing significantly. Figs. 4(c) and 4(d) depict the changes of bending moment of pile and axial force of anchor cable under different cohesions of pile and soil. As the cohesion increases, the bending moment of pile and the axial force of anchor cable increase, too. This is because the increasing cohesion results in a better bonding effect of pile and soil, leading to more stress applying on pile. Figs. 4(e) and 4(f) illustrates the variations of bending moment of pile and axial force of anchor cable with increasing stiffness of pile. The increasing stiffness causes the increase of bending moment of pile and decrease of axial force of anchor cable. The reasons may be that with the increase of pile stiffness, the supporting pile would suffer more stress of soil, making the soil suffering less stress and resulting in the increase of bending moment of pile and decrease of axial force of anchor cable.

Fig. 5 and Table 4 present the comparison results of monitoring data and calculated results. The monitoring data shows that the maximum interior bending moment is $158.7 \mathrm{kN} \bullet \mathrm{m}$ located in $\mathrm{z}$ $=-10 \mathrm{~m}$, while the numerical results are $159.79 \mathrm{kN} \bullet \mathrm{m}$ located in $z=-9.15 \mathrm{~m}$. The maximum exterior bending moment of monitoring data is $-152.3 \mathrm{kN} \cdot \mathrm{m}$ in the depth of $z=-14 \mathrm{~m}$, while the maximum exterior bending moment of calculated results is $-139.68 \mathrm{kN} \cdot \mathrm{m}$ in the depth of $\mathrm{z}=$ $-14.64 \mathrm{~m}$. The monitoring data agree well with the measured data, showing the accuracy and reliability of the numerical simulation.

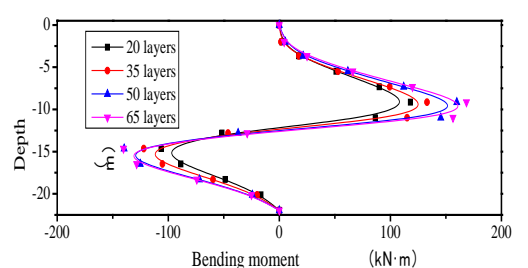

(a) Bending moment of pile (grid layer)

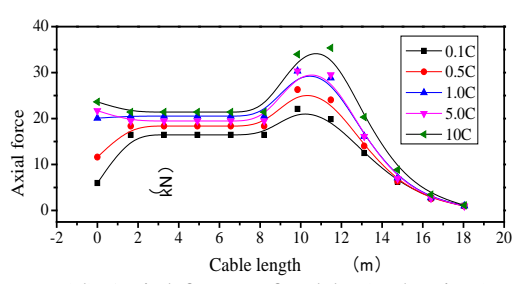

(d) Axial force of cable (cohesion)

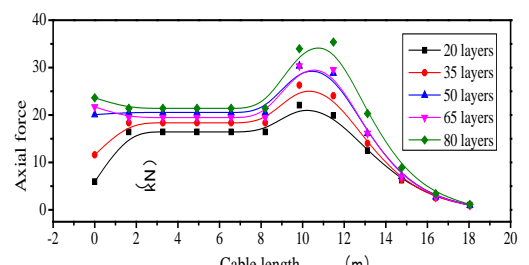

(b) axial force of cable (grid layer)

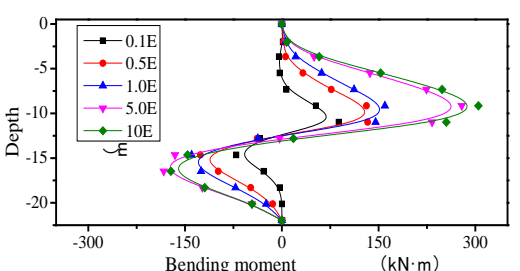

(e) Bending moment of pile (stiffness)

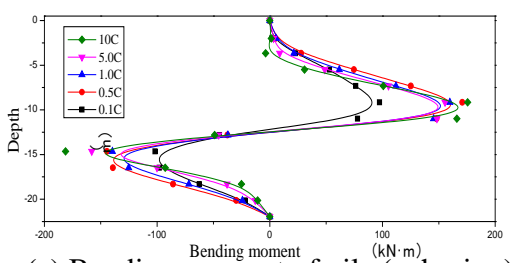

(c) Bending moment of pile (cohesion)

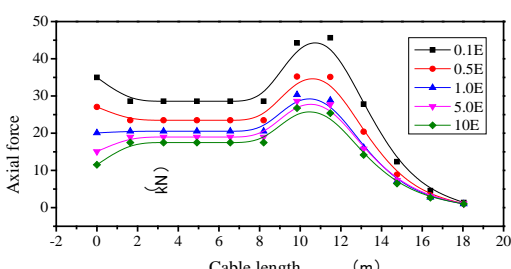

(f) Axial force of cable (stiffness)

Fig. 4 Bending moments of pile and axial forces of cable with varying grid

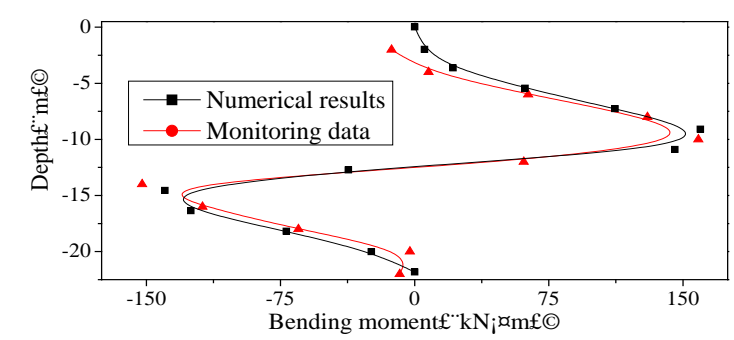

Fig. 5 Numerical simulation results and measured data
Table 4 Measured data and numerical simulation data

\begin{tabular}{ccccc}
\hline \multirow{2}{*}{$\begin{array}{c}\text { Data } \\
\text { source }\end{array}$} & \multicolumn{2}{c}{ Max interior } & \multicolumn{2}{c}{$\begin{array}{c}\text { Max exterior } \\
\text { bending moment }\end{array}$} \\
\cline { 2 - 5 } & $\begin{array}{c}\text { value } \\
(\mathrm{kN} \bullet \mathrm{m})\end{array}$ & $\begin{array}{c}\text { depth } \\
(\mathrm{m})\end{array}$ & $\begin{array}{c}\text { value } \\
(\mathrm{kN} \bullet \mathrm{m})\end{array}$ & $\begin{array}{c}\text { depth } \\
(\mathrm{m})\end{array}$ \\
\hline Monitoring & 158.7 & -10 & -152.3 & -14 \\
\hline Calculating & 159.79 & -9.15 & -139.68 & -14.64 \\
\hline Errors(\%) & 0.7 & 8.5 & 8.286 & 4.571 \\
\hline
\end{tabular}




\section{Conclusions}

The comparisons of monitoring data and numerical simulations show that when obtaining the reasonable parameters and considering the interaction effects of soil, cable and pile, the numerical simulation is accurate and reliable. The vertical grid layer, the cohesion of pile and soil, the pile stiffness and other parameters can significantly influence on the mechanical behaviors of pile and anchor cable. When excavation is finished, the results show the maximum axial force of anchor cable located in the former part while its value is constant for freedom segment, which agrees well with other researchers' results.

\section{References:}

[1] JB Cao. Study on mechanics and application of pile-anchor in deep foundation pit [D]. Wuhan: China University of Geosciences, 2010. (in Chinese)

[2] CK Shen, S Bang and LR Herrman. Ground movement analysis of earth support system [J]. J. Geotech. Engrg.Div, ASCE, 1981,107(12):1609-1624.

[3] CG Jiang, XX Lin, JX Huang, GD Lv and SF Yu. Deformation monitoring and primary analysis of supporting structure of pile-anchor system in foundation pit [J]. Geotechnical engineering, 2002,5(8):55-56. (in Chinese) 